\title{
MOVING CENTER STAGE: Dance and Modernization in Late Twentieth Century Montreal
}

\author{
BLAIR A. RUBLE
}

(Photos Curated by Eli Larin, University of Concordia, Montreal, QC).

Writing about the thousands of amateur and semiprofessional dancers who were soon to descend on a local dance competition on April 26, 2016, the homegrown newspaper of the off-island Montreal bedroom community of Terrebonne, Journal La Revue de Terrebonne noted that the Montreal region of some four millions souls was home to as many dance schools 96 - as Italy. ${ }^{1}$ That weekend, 10,000 dancers would arrive at an otherwise unremarkable suburb of about 100,000 nestled on the St. Lawrence River's north shore, thereby confirming once more that Montreal had become one of the world's hot spots for dance.

Homegrown dancers and choreographers were not just local, of course. At the same time as the Terrebonne dance invasion, Montreal companies were appearing on stages around the world, often to rave reviews. Performance dance has entered the soul of Quebec where, just over a half-century ago, the art form had been all but banned by the moral strictures of clerical traditionalists. The city's and province's explosion in all manner of dance - and other arts - tracked remarkable political, social, cultural, and spiritual transformations that swept across Quebec society throughout the mid-twentieth century. The story of dance offers one insightful piece of the larger tale of a sudden embrace of modernity.

Mimeographs, Television Screens, and Immigrants

Quebec came out of World War II stuck in a time warp that placed La Belle Province at odds with much of North
America. Transformation came as the rest of the continent increasingly became incorporated into what would grow in a few years into the most dynamically mobile continental economy in world history. ${ }^{2}$ Even the forces of traditionalism so prevalent in Quebec could not resist.

Nothing escaped this transformation, including performance dance. Beginning almost immediately following the World War II, those Montrealers connected to continental trends in the arts began to push back against repressive policies. New Montrealers debarking from war-torn Europe brought their cultural tastes and expectations with them. Before 1945, the only serious dance reaching Montreal stages was performed by visiting companies made up of Americans, Europeans and displaced Russians (including Ruth St. Denis, Mary Wigman, Charles Weidman, Isadora Duncan, Anna Pavlova, and various legacy companies from Les Ballets Russes). ${ }^{3}$ By the 1960s, Montreal had its own classical company and the first of what would become a panoply of modern dance troupes.

The opening bell in the culture wars against clerical hegemony came in August 1948, with the artistic manifesto entitled Le Refus Global issued by a handful of artists propelled a new vision for Quebec culture. ${ }^{4}$ This proclamation was the brash cry of abstract artists influenced by the French surrealists. Enraged at the "cassocks that have remained the sole repositories of faith, knowledge, truth, and national wealth," the group took on the title of Les Automatistes. 
In August 1948, sixteen of their number composed and self-published a manifesto proclaiming the "untamed need for liberation," "resplendent anarchy," and extoling the creative force of the subconscious. Mimeographed in four hundred copies, their platform sold for a dollar a piece at a local Montreal bookstore. This seemingly obscure artistic declaration set the tone for intense cultural debates to follow. Twenty-three year old dancer, choreographer, painter and sculptor Françoise Sullivan was among the sixteen signatories. ${ }^{5}$

Sullivan had grown up in Montreal, trained in classical dance by Gérald Crevier. She studied painting at École des beaux-arts de Montréal as well, where she became friends with Borduas and others among Les Automatistes. ${ }^{6}$ In 1945 she moved to New York where she delved into modern dance with Franziska Boas, Martha Graham, and Louis Horst. Returning to her native city in 1948, Sullivan performed with Jean-Paul Riopelle and Maurice Perron in a snow-covered field near Mont-St Hilaire in what proved to be a landmark work in Quebec modern dance: Danse dans la neige (Dance in the Snow). ${ }^{7}$

As Sullivan's career reveals, Les Automatistes emerged just as the modern age burst forth in Quebec. Economic and political transformation swept away an old order dominated by Anglo-economic and Franco-clerical power; new technologies and the arrival of post-war immigrants transformed the possibilities for cultural renewal. Dance would become a major arena for this change; and television would bring it to the forefront of cultural change.

Broadcasting in Canada is an expensive undertaking given the country's vast distances punctuated by a relatively few settlements and cities of any size. Initial telecasts began in Montreal and Toronto in September 1952, with the first national service following in $1958 .^{8}$ This expansive public enterprise provided important shared content to all Canadians and offered a counterweight to the powerful American radio and television networks leaking across the border.

The challenges confronting English language broadcasting in Canada were magnified in the French service. Audiences were smaller and more dispersed; and readily available content proved more difficult to find. The task of creating a distinctively French-Québécois television fell to Radio-Canada in Montreal. ${ }^{9}$

Working within a limited budget, producers turned to the local performing arts community for content. Montreal playwrights and actors created madly popular drama and comedy series such as La famille Plouffe, based on a novel by Roger Lemelin. ${ }^{10}$ Set in a working class Quebec family, this and other shows brought Quebec daily life and language to the screen. These efforts provided steady employment for Montreal writers, directors, actors and musicians; an important safety net that enabled survival in an otherwise harsh economic environment. ${ }^{11}$

Beyond drama, variety shows came to be a convenient way to fill time by promoting local comedians, musicians and dancers. Given the uncongenial climate for dance, producers found they had to rely on many dance professionals who had immigrated from abroad or who had disguised their Québécois identity behind made up foreign — usually Russian sounding — names.

\section{The Founders}

Maurice Lacasse, the son of a ballroom dance teacher and grandson of a legendary folk violinist, was born in Montreal in 1906. His father, Adelard, moved to the city and became a schoolteacher after having been forced to leave the family's country home a few years before Maurice was born. Adelard's patrons raised money to send him to New York to learn the latest crazes -- such as the Waltz, and Cakewalk - where he studied with Irene and Vernon Castle before returning to make his living from a St. Lawrence Boulevard studio. Maurice grew up surrounded by dance and music. ${ }^{12}$

At twenty, Maurice ran off with a Frenchwoman - Carmen Sierra - who was a year his senior. After eloping, Maurice and Carmen connected with a company of Russian balalaika musicians and dancers. The group invited Maurice and Carmen to join them when one of their acts fell to injury. Their combination of toe, tap, and acrobatic dancing became an instant hit and the couple embarked on a five year North American tour. It was during this time that Maurice - like many North American-born dancers - changed his 


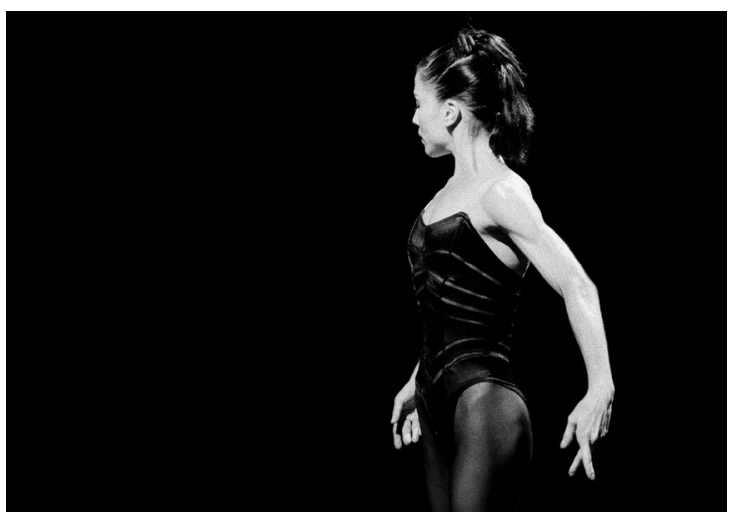

Laurent Ziegler — http://unstill.net/. Amjad by La La La

Human Steps, performed in May 2008 in Vienna,

Austria

name to the Russian-sounding Morenoff to try to associate with the success of Diaghilev's Ballets Russes. ${ }^{13}$

The Morenoffs returned to Montreal in 1931 as the Great Depression set in. They opened a dance studio and library in a triplex in Montreal's east end that would remain a fixture on the Montreal dance scene until their deaths in the early 1990s (Carmen in 1990; and Maurice in 1993). The couple successfully trained the first generation of French Canadian male dancers including Fernand Nault, Roland Lorrain, Marc Beaudet, and Michel Boudot. ${ }^{14}$

Their contemporary Gérard Crevier was born in Longueuil, Quebec in 1912 to a French Canadian father and Irish mother. Crevier fell in love with dance at the age of ten after seeing Anna Pavlova dance at the Orpheum Theatre. Pavlova inspired the young boy to enroll in Ezzak Ruvenoff's dance school, where he studied ballet while being instructed in tap by Dora Marshall, who would dance at Radio City Music Hall in New York. His dance career began by filling in the intermissions between shows at local movie theatres. He would marry Elisabeth "Zette" Devaux, a dancer from the French West Indies, and head off to England at the age of twenty to join the corps de ballet of the Sadler's Wells Company. ${ }^{15}$

Crevier started teaching in Montreal during the 1930s before heading back to Europe in the Canadian Army during the Second World War. Andrée

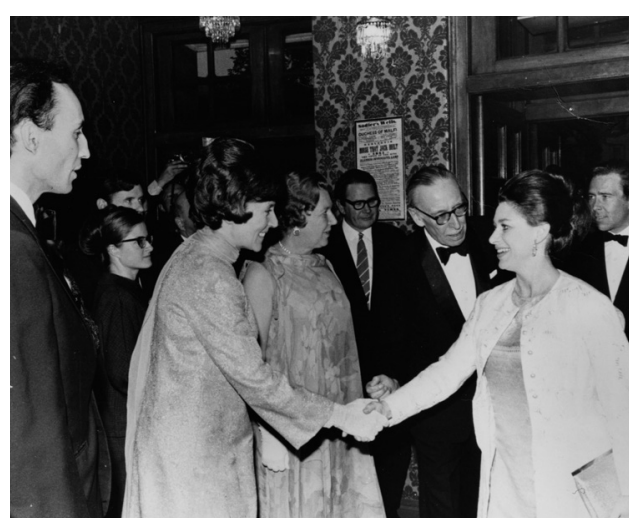

Madame Chiraeff is greeted by HRH Princess Margaret in the Sadlers Wells Theatre, Courtesy of Les Grands

Ballets Canadiens de Montréal

Millaire, Lise Gagnier, and Françoise Sullivan were among his students. He organized successful recitals and, following the war, brought the Royal Academy of Dance ballet syllabus back to the city. His small company featuring his own choreography appeared widely following the war, including a highly successful performance at the third Canadian Ballet Festival held in Montreal in $1950 .{ }^{16}$ Crevier's Les BalletsQuébec folded in 1952, after which he briefly joined the new National Ballet of Canada in Toronto before leaving the dance world all together while relocating to Venice, Florida. ${ }^{17}$

Montreal dance's third seminal figure Ludmilla (Otzup-Gorny) Chiriaeff arrived in Montreal as an immigrant from war-torn Europe in 1952. Chiriaeff was born to Russian parents in Riga in 1924, and grew up in Berlin studying with former dancers from the Bolshoi. Michel Fokine was among the many prominent émigré Russian artists and performers who passed through the exiled family's home in the German capital. Chiriaeff performed small roles in de Basil's Ballets Russes and continued dancing throughout World War II, ending up in Geneva. Marrying Russian set designer Alexis Chiriaeff, she taught ballet and danced with local companies on stage and in a dance film Danse Solitaire. ${ }^{18}$

Chiriaeff arrived in Montreal in the middle of the frigid 1951-1952 winter. Stepping out for a breath of air on her first evening in town she saw her name 
in lights. Danse Solitaire happened to be showing in a theater down the street from her hotel. Her love affair with Montreal was sealed. ${ }^{19}$ She began teaching dance and formed her own group - Les Ballets Chiriaeff - in response to the insatiable demand for content by Montreal television. These shows introduced local audiences to performance dance.

By the time Les Ballets Chiriaeff walked onto a theater stage as Les Grands Ballets Canadiens in 1957, Chiriaeff already had secured an enthusiastic audience for her group. Now named more grandly, the company performed to solid reviews at the Jacob's Pillow summer season in Massachusetts and elsewhere across Canada. She recruited French Canadian dancers - including Fernand Nault who had been working with the American Ballet Theatre in New York - and reached out to the Roman Catholic Church - performing religiously inspired programs in prominent Montreal churches. ${ }^{20}$

These activities established a strong connection between her company and an emerging French Canadian identity. This association deepened in the future as she expanded her efforts to include a school and a library, which provided an all-important institutional base for the Montreal dance community. By the 1960s, Les Grands Ballets Canadiens had joined with the Royal Winnipeg Ballet and the National Ballet of Canada as the country's triumvirate of classical dance. ${ }^{21}$

The Morenoffs, Crevier, and Chiriaeff teamed up with other immigrants who brought international dance culture to French Canada during the middle years of the twentieth century. These included Ruth Sorel, who was born to Polish parents - the Abramowitz family in Germany in 1907, Elizabeth Leese, and Séda Zaré.

Sorel had launched a well-regarded career in Germany - including a turn with the Berlin Opera under Bruno Walter - before the Nazis came to power in 1933. She left for Poland, established her own school and toured internationally before marrying playwright Michel Choromanski. Sorel eventually made her way to Montreal in 1944, where she opened a dance studio at the Westmont YMCA and formed a small modern group in the German expressionist tradition. She choreographed new ballets drawing on Quebec and Canadian themes - such as La Gaspesienne (1949) - and took her dancers to New York as well as across Canada. The couple returned to Poland in the mid-1950s. ${ }^{22}$

Elizabeth Leese, the child of an academic family of mixed Danish and German heritage, was born in 1916. She studied modern dance in Germany before receiving classical training in Paris with former St. Petersburg teachers. Joining the Swiss Trudi Schoop modern dance company, Leese travelled to North America for the first time in 1937. Eventually ending up in England, she married Canadian journalist Kenneth Johnstone and settled in Toronto in 1939. Entering a Toronto dance scene dominated by Russian émigré Boris Volkoff, she carved out a distinctive place for herself promoting modern dance.

In 1944, Leese and Johnstone moved to Montreal and began spending time in New York where she took courses from Martha Graham, Doris Humphrey, and Hanya Holm, Antony Tudor, Margaret Craske, Edward Caton, and George Balanchine. Moving easily among Montreal's language communities, she operated a successful school. She taught at both McGill and the Université de Montréal, and formed the Montreal Theatre Ballet with her student Brian Macdonald. By 1960 she had become associated with Les Grands Ballets, where she remained until she died too young from cancer in $1962 .^{23}$

Séda Zaré was born in 1911 to a successful Armenian family involved in the Baku oil trade. Her family fled to England in 1921 following the Turkish massacre of Armenians. There, she went to boarding school, studied ballet with Nicolas Legat, and free dance with Margaret Morris and J. Gordon Denning. She eventually left for Paris to become a student of Boris Kniaseff, prior to moving to Germany. A favored student of Alexandra Nikolaeva in Berlin, Zaré took over Nikolaeva's school upon her teacher's retirement. A young Ludmilla Chiriaeff began studying dance at the school during these years.

Changing her name during the war in response to Nazi suspicion, Zaré enjoyed a successful dance career and toured widely throughout Europe once the war ended. She and her family emigrated to Canada as war refugees in 1950. She opened Russian-style schools in Montreal, Trois Rivieres, and Shawinigan, producing 


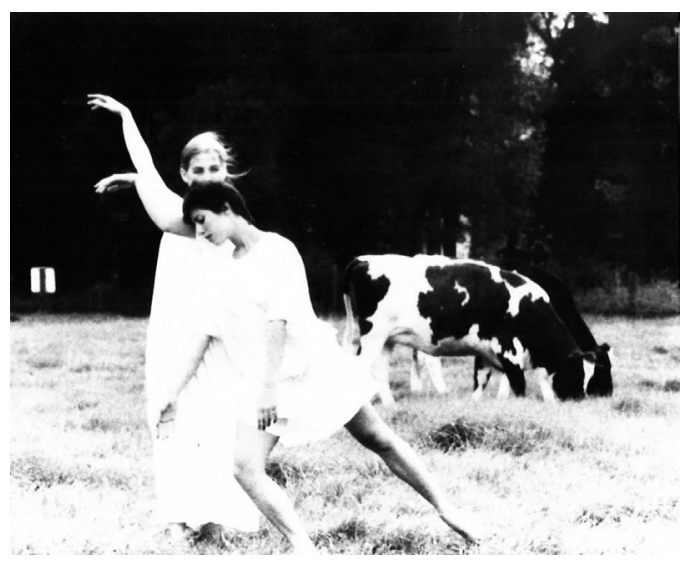

Les Dames aux Vaches (Experimental farm, Vancouver), JeanPierre Perreault, 1978. On the photo: Tassy Teekman and Elaine Rudnicki. Photo : Jean-Pierre Perreault. Collection Serge

Trouillet, Fonds Jean-Pierre Perreault, BAnQ

students such as Bernadette Beliveau and Marie Cote, who would enjoy successful professional careers in Toronto, Lille, and elsewhere. She also launched a highly successful collaboration with the City of Montreal's Parks and Recreation Service, which brought creative dance to a broader public. ${ }^{24}$

Montreal dance pioneers Sullivan, Crevier, the Morenoffs, Sorel, Lesee, and Zaré provided a durable foundation for a vibrant and abundant dance scene. They extended roots from the rather barren Quebec cultural landscape - far too long dominated by clerical traditionalists who excoriated dance as immoral deep into some of the most bountiful among the century's dance scenes including Berlin, Paris, London, New York and, by extension, Moscow and St. Petersburg. Drawing fresh energy from the social and political upheavals that were sweeping across the city and province at the dawn of the 1960s, these pioneers created a fresh and distinctive Montreal dance culture that they could call their own.

\section{Les Grands Ballet Canadiens}

The move of Les Ballets Chiriaeff from the television studio to the theatrical stage and its accompanying metamorphosis into Les Grands Ballets Canadiens marks a moment of consolidation for Montre-

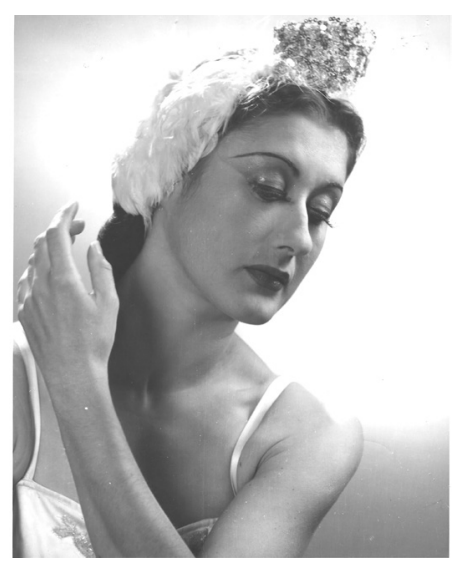

Eva von Gencsy in White Swan in Swan Lake excerpts, 1951 photographed by Phillips-Gutkin. Courtesy of Canada's Royal Winnipeg Ballet Archives.

al dance. Montreal performance dance now claimed a core institution that would grow into a complete unit with a high quality school and research facility. Les Grands Ballets provided a touchstone for homegrown talent, as well as a point of connection with the larger dance world through which accomplished artists were drawn to the city and Montreal dance journeyed out into the world.

By joining the ranks of Canada's top classical companies together with the Royal Winnipeg Ballet and the National Ballet of Canada, Les Grands Ballets arrived at just the right moment to become an institution of Canadian significance. ${ }^{25}$ Emerging as it did as a French language oriented institution as Quebec nationalism took flight, the company cemented a powerful place for itself in the French Canadian imagination. Les Grands Ballets provided the bedrock on which a diverse and dynamic performance dance scene could grow.

The Canada Council - the Federal Government's grant-making agency for the arts - attempted to untangle the adversarial relationships that had grown up among the three dominant classical companies. ${ }^{26}$ In 1962, the Council's Arts Supervisor Peter Dwyer commissioned a survey and evaluation of the Canadian dance scene by Lincoln Kirstein, founder of the New York City Ballet, and British ballet critic Richard Buck- 
le. Noting the Russian traditions of Les Grands Ballets, Kirstein recommended that Canadian ballet start over again with Montreal as a focal point. Council bureaucrats ignored this recommendation and continued funding all three companies due, no doubt, to bureaucratic and political exigencies. ${ }^{27}$

Chiriaeff built her company from an original troupe of sixteen dancers by melding her school with the company. In 1958, she reorganized her dance studio into the Académie des grands ballets canadiens to prepare performers for her company. In 1970, that institution grew into L'École supérieure de danse du Québec, a foundational training center which - together with important programs at l'Université du Québec à Montréal (l'UQÀM), Concordia University, and l'Université de Montréal - form the core for dance education in the city and province. Chiriaeff stepped down as Les Grands Ballets artistic director in 1974 to devote her energies to the school. ${ }^{28}$

Chiriaeff assiduously drew on Montreal talent to develop her company. She invited Fernand Nault to assume the artistic directorship for the company in 1965. Trained by Maurice Morenoff, Nault had enjoyed success at the New York-based American Ballet Theatre beginning in 1944. In 1960, he retired from performing to assume the directorship of the School of American Ballet. This experience proved crucial for advancing Chiariff's artistic and pedagogical aspirations for the company.

On stage, Nault choreographed an exciting version of Slaughter on Tenth Avenue for CBC television which featured him dancing together with that of Elizabeth Leese. His Carmina Burana, performed at the Expo '67 World's Fair - and his choreography for The Who's rock opera Tommy - brought the company a wildly enthusiastic younger following both at home and abroad. These successes enhanced box office revenues as well as winning a world-wide fan base, thereby placing Les Grands Ballets on the international map. ${ }^{29}$

\section{No Less a Revolution For Being Quiet}

The social, political, and cultural forces unleased by the "Quiet Revolution" secularized Quebec identity and nationalism. The arts played a significant role in this transformation precisely because the process rested on the expression of public and private identities. $^{30}$ The theater community constituted a radicalizing vanguard pushing forward new voices who were striving to decipher the meaning of everyday experiences on stage. ${ }^{31}$

Chiriaeff's Les Grands Ballets Canadiens continued to grow throughout the period, solidifying both its organizational capacities and its artistic signature. In September 1963, the company became an anchor tenant for Mayor Jean Drapeau's ambitious performing arts center, Place des Arts, taking up permanent residence in the well-appointed Salle Wilfrid-Pelletier. ${ }^{32}$ Simultaneously, Chiriaeff consolidated the company's internal organization and nurtured a dedicated and effective permanent administrative staff who helped her expand every aspect of the company's operations.

She was able to elevate the company's original Académie des grands ballets canadiens into a major professional training program for rising performers, l'École supérieure de danse du Québec. ${ }^{33}$ Her dedication to dance education never ebbed, as she devoted the remainder of her career to the school after relinquishing her post as the company's Artistic Director in 1974. Failing health forced her retirement in 1992, just a few years prior to her death in 1994 at the age of $72 .^{34}$

Chiriaeff was followed as artistic director between 1974 and 1978 by Brian MacDonald who clarified and refined the company's image, leading successful international tours and producing legendarily popular works. Chiriaeff's previous investment in institutional development paid large dividends following MacDonald's departure as, between 1978 and 1985, the company's artistic vision was successfully curated by committee for nine years before ballet mistress Linda Stearns assumed the helm in late 1987 as sole artistic director. American Lawrence Rhodes followed in 1989, to be succeeded by Macedonian-born Gradimir Pankov a decade later, and by Italian Ivan Cavallari in 2017. ${ }^{35}$

This constancy supported a commitment to original work, often commissioned by some of Canada's leading choreographers who have garnered international renown for the company. ${ }^{36}$ For example, MacDonald invited Fernand Nault on board as resident choreog- 


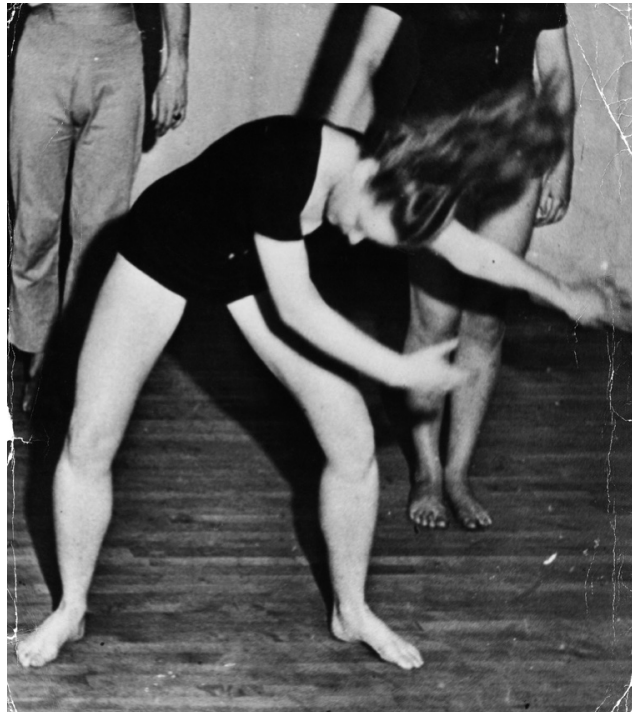

Françoise Sullivan in repetition. The Boas School of Danse,

New York, circa 1945

Photo: Personal archives of Françoise Sullivan

rapher. During his time with the company, Nault took full advantage of dance joining theater, opera and music as the main pillars of the World Festival program associated with Expo 67.

The company's ethos fit well with Quebec's uncertain political atmosphere and became part of a period of exceptional artistic volatility in Montreal and the province. Nonetheless, as Iro Valaskakis Tembeck tellingly concludes a 2004 article exploring the complex dynamics of dance and Montreal politics that appeared in Selma Landen Odom and Mary Jane Warner's Canadian Dance, "Les Grands Ballets' broad artistic vision does not particularly reflect a Quebecois sensibility, either in choreographic treatment or in thematic concerns. Nevertheless, when the rise of nationalism spilled over onto the performing arts scene in Quebec, the company strategically required its dancers to alter their names to more French-sounding ones, because it had been unofficially denounced as not sufficiently representative of the French-Canadian identity. During the 1970s Sacha Belinsky became Alexandre Belin, Roslyn Faierstein was billed as Roseline Forrestter, and Sylvia Kinal became known as Sylvie Cheva-

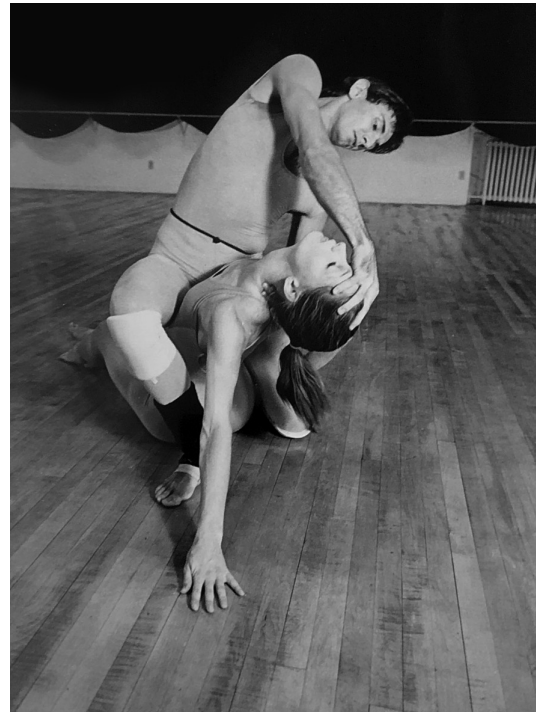

Le Songe (1981). Choreography by Martine Époque,

Dancers: Manon Levac and Gilles Brisson.

Photography by Roger Dufresne

lier. If the previous generation headed by the LacasseMorenoffs had sought Russian sounding names to emulate Diaghilev, we now witness a fascinating reversal in this conscious gesture to Frenchify stage names. ${ }^{37}$

Tembeck goes on to note that Montreal's best known 1980s dancers were in modern and experimental dance. The city's pulsating dance scene nonetheless rested on the solid base provided by Les Grands Ballets and its schools which were joined by notable dance programs at several local universities. In the process, dance entered the city's cultural bloodstream moving from precious stage art to public expression of a quickly changing society.

\section{Formative Turns}

Three contemporary dance companies took shape in the chaotic political, social, cultural, and artistic environment enveloping Montreal during the late 1960s and 1970s. Each fashioned the foundation on which the city's innovative and vibrant dance community continues to swirl: Le Groupe de la Place Royale (1966-left Montreal, 1977-2009), Le Groupe Nouvelle Aire (19681982), and Le Ballet Jazz de Montrèal (1972-Present). 
In 1966, Jeanne Renaud founded a new company named after a small Old Montreal square outside her studio. Le Groupe de la Place Royal quickly became a focal point for Canadian modern dance. ${ }^{38}$

Renaud had been a young admirer of Les Automatistes, and she had embraced the principals set forth in their 1948 manifesto Le Refus Global even as she was not herself a signatory to the historic petition. ${ }^{39} \mathrm{In}$ stead, she headed off to New York, Paris and London to study with some of modern dance's formative creators including Hanya Holm, Mary Anthony, and Merce Cunningham.

Renaud returned to her native Montreal in the late 1950s and, by the mid-1960s, was looking for ways to bring together her interest in modern dance movement, staging, decor, and costumes. Finding a dearth of opportunities, she founded her own company and school in 1966 . To succeed, she had to take on a broad assortment of performance and administrative roles. Over the company's first half-dozen years she created thirty-one works that she performed in Montreal and across Canada and the United States.

Renaud did not limit her boundless energies to her own company. She held a number of important arts administrative positions with Canada Council, Quebec's Ministére des affairs culturelles, l'UQÀM, and Les Grands Ballets Canadiens, where she spent time as coartistic director with Linda Stearns. She also found time to fit in teaching in New York as well as Paris, and joined with Françoise Riopelle in establishing L'École de Danse Moderne de Montréal.

Renaud turned the artistic and leadership reins of Le Groupe over to Peter Boneham upon her departure from the company in 1971. Boneham attracted a number of talented younger dancers including Jean-Pierre Perreault, who assumed greater responsibilities in running the company in the years ahead. Artistically, Le Groupe approached contemporary dance in ways pioneered at the time by Merce Cunningham; particularly by developing choreography independent of music. The resulting randomness enabled individual company members to demonstrate their personal artistic visions.
The company experimented with melding new technologies and movement, as in Perreault's Les Dames aux Vaches (1975), which was performed with projected images of cows (and, when on tour in Vancouver, in an actual cow pasture). Later, Boneham teamed with soprano Pauline Vaillancourt to connect sung poetry to movement. ${ }^{40}$ He continued these "opera for dancers" after the company relocated to Ottawa in $1977 .{ }^{41}$

After becoming progressively frustrated with an inability to generate adequate funding in Montreal, Boneham relocated to Ottawa, where the group established itself as a more open group enterprise. ${ }^{42}$ Renamed Le Group Dance Lab in 1988, the company and its attached training studios became a fixture on the Ottawa scene, gaining international renown and exerting considerable artistic influence over the Canadian national dance scene. ${ }^{43}$ Securing more generous support from the Ontario provincial government than had been the case in Quebec, Boneham nurtured a generation of leading Canadian dancers and choreographers who constantly experimented with new forms, expanded their movement vocabulary, and explored the interaction between human movement and technology. However, the company could not survive Boneham's retirement in 2008, and ceased to exist the following year. ${ }^{44}$

French immigrants Rose-Marie Lèbe and Martine Époque founded Le Groupe Nouvelle Aire in 1968 as an extra-curricular activity for dance students enrolled in the l'Université de Montréal's physical education program. ${ }^{45}$ While Le Groupe de la Place Royal was apolitical, Le Groupe Nouvelle Aire embraced and gave expression to the upheavals of the moment. ${ }^{46}$ Époque charged the group with creating a "Québécois" dance vocabulary which could be integrated into the program's curriculum. Lèbe and Époque recruited students from across the university, creating a safe place for the clash of diverse approaches to dance. Over time, those students more dedicated to dance came to dominate the company, encouraging innovative choreographers and reaching out to Québec composers. PaulAndré Fortier, Édouard Lock, Ginette Laurin, Louise Lecavalier, Daniel Léveillé and other future stalwarts of the Montreal dance community started their careers with Le Groupe. 


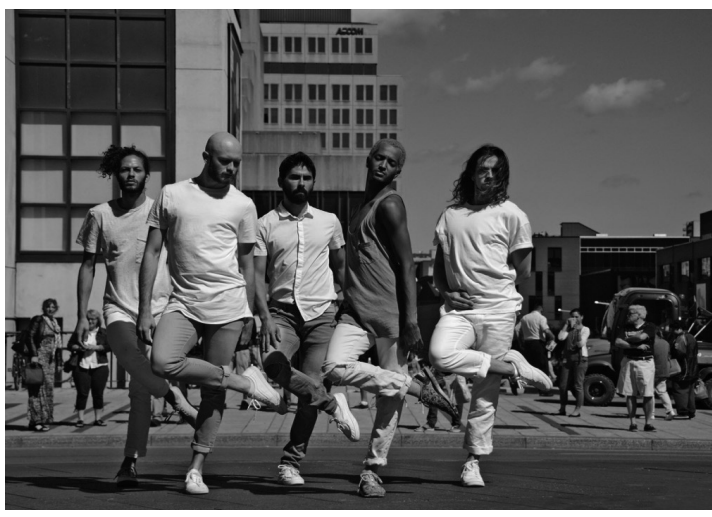

Dancers on the image (from left to right): Abe Simon Mijnheer, Alexandre Morin, Gabriel Painchaud, Jossua Collin, Jean-Benoit Labrecque; Choreographer : Sébastien Provencher; Photography by Jackie Hopfinger

Époque left to join the faculty at l'UQÀM in 1980 and the company ceased operations in 1982, formally dissolving five years later. She would go on the chair that university's dance program and become a key figure in the Montreal dance community. ${ }^{47}$ Her numerous contributions would include creating l'Agora de la danse. ${ }^{48}$

Fortier, who was a dancer in the company, formed his own group and, together with Daniel Jackson, established Montréal Danse. He emerged as a leading choreographer working with several companies at home and abroad including Les Grands Ballets Canadiens, he also joined the l'UQÀM faculty. His ability to surround himself with top talent helped to attract some of the most impressive innovators in dance to the city. ${ }^{49}$

Laurin launched her career as a young dancer just as Le Groupe Nouvelle Aire began to perform. Having trained with such Montreal luminaries as Fernand Nault, Madame Voronova and Marjorie Lambert, she studied improvisation in New York and worked at home as well as internationally. She would later produce major works with several Montreal companies including Danse-Cité, Montréal Danse and Les Grands Ballets Canadiens.

Daniel Léveillé became an important Montreal choreographer, working closely with new wave avantgarde dance makers and integrating sexuality into per-

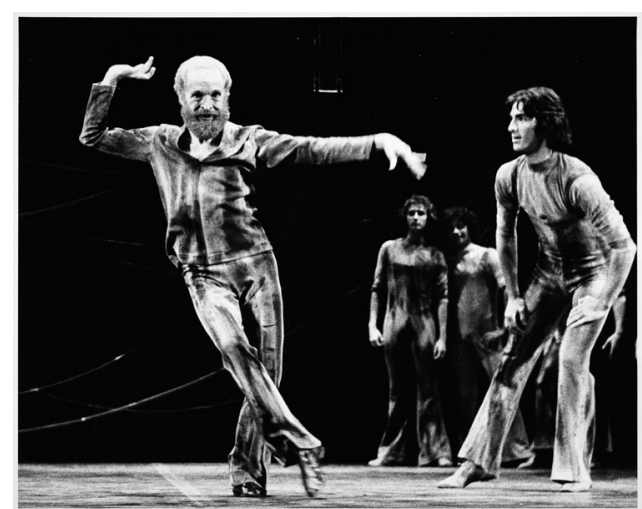

John Stanzel in the role of Uncle Ernie in Tommy (1970) by Les Grands Ballets Canadiens de Montréal, Photo by André le Coz.

Source: Bibliothèque de la danse Vincent-Warren

formance. Together with the company's other leading lights, Fortier, Laurin and Léveillé became leaders driving contemporary dance in Montreal over several decades.

Édouard Lock took the company's exciting inventiveness abroad. Born in Casablanca, Lock enrolled at Concordia University, where he wanted to study film and literature. He matriculated just as the Concordia dance program was taking off. He studied with Nora Hemenway of Le Groupe de la Place Royale and others at Concordia as well as with Merce Cunningham. By the late 1970s he had begun to try choreography, often working with others on major projects including works for Les Grands Ballets Canadiens.

Lock's career blossomed after he founded La La La Human Steps in 1980, where he would gain international recognition for choreographing the music of such rock musicians as David Bowie, Frank Zappa, and Skinny Puppy. The company has garnered praise around the world..$^{50}$

Though short lived, Le Groupe Nouvelle Aire exerted a lasting influence over Montreal dance culture. Its organizers, choreographers, and dancers became embedded in dance education, while the performers and choreographers extended the reach of contemporary dance in directions that demanded attention both at home and abroad. This success as a cultural incuba- 
tor was rooted in a desire to participate in the larger cultural upheavals of the day by defining a new Québécois identity through movement. Like the battle over sovereignty, its impact outlasted the immediate struggles of the 1960s and 1970s.

A third essential group in the city - Le Ballets Jazz de Montréal - would become among the city's most successful cultural initiatives of the past half-century. The company and its dance form labeled "ballet jazz" by its primary creator Eva von Gencsy swept North America by storm and created a dance boom throughout Quebec. School children, housewives, and professional dancers formed a vast network of dance schools and studios promoting a popular audience which has continued to sustain a dance-crazed Québécois society long after notoriety had worn off. The company continues to be among Canada's most travelled cultural enterprises drawing avid audiences around the world.

Eva von Gencsy left her native Hungary for Canada in 1948. She previously enjoyed success, having been trained at V. G. Troyanoff's Russian Academy in Budapest before the outbreak of World War II. Following the war she joined the Salzburg Landes Theatre as a soloist. She was lured across the Atlantic by the Winnipeg Ballet where she earned accolades for her clean, perky, expressive, and endearing style. ${ }^{51}$ Following a fire that had destroyed the Winnipeg company's sets and costumes, Ludmilla Chiriaeff invited her to Montreal where von Gencsy, like Chiriaeff, would find an enduring place in the North American dance world. A leading dancer in Les Ballets Chiriaeff, she gained an enthusiastic following from her television appearances. Von Gencsy left the company once it evolved into Les Grands Ballets Canadiens in order to continue working in television. By the late 1960s she had become a beloved popular cultural figure and bestowed by French Radio Canada with the title of best dancer. ${ }^{52}$

Von Gencsy devoted considerable energy to teaching. Already in 1953, she was an instructor at the Banff School of Fine Arts. A few years later she discovered jazz as a dance form and began teaching what she came to call "jazz ballet" at Banff and, later, at the Saidye Bronfman Centre and Séda Zarés Montreal Profession- al Dance Center. She used jazz as a means for adding spontaneity and joy to the dance studio. As the number of students and accolades grew she decided to move the form to the stage. She joined with French immigrant Geneviève Salbaing and Haitian immigrant Eddy Toussaint to establish a performing company Le Ballets Jazz de Montréal.

While Toussaint would leave the company to form his own troupe a year later, von Gencsy and her partners successfully guided the company forward. Winning major notices in Paris, Varna, and elsewhere, von Gencsy regularly taught across Europe and North America. ${ }^{53}$ She would be a towering figure in the Quebec dance community until her death in 2013 following a heart attack suffered at the age of eighty-nine while introducing two of her works at the company's fortieth anniversary performance. ${ }^{54}$

Von Gencsy, Salbaing, and Toussaint - like von Gencsy and Chiriaeff - were immigrants open to fresh ideas at a time of unusual creativity and invention in Montreal. They shaped the city's dance community as a leading center for contemporary dance, and engaged the complex artistic, political, and cultural currents washing over the city as the Quiet Revolution evolved into a political contest over Quebec sovereignty.

These three successful dance companies of the 1960s and 1970s — Le Groupe de la Place Royale, Le Groupe Nouvelle Aire, and Les Ballets Jazz de Montréal — responded to the deep and profound identity conflicts of the era unleased by Quebec's modernization during its Quiet Revolution. Each represented a different face of those struggles. Le Groupe de la Place Royale remained dedicated to dance in its abstract form eventually finding new fertile ground in Ontario. Le Groupe Nouvelle Aire became rooted itself in the sovereignty project of emerging secular nationalists. Les Ballets Jazz de Montréal drew on and, in turn, enriched an ever-less traditional popular culture and society more intent on fun than piety.

Together the insinuated dance into the center of a deep and profound battle for the hearts and minds of the Québécois. As the indubitable dance historian Tembeck observed in her exploration of politics and dance for Odom and Warner, Montreal dance 
history "has proven that dance can very easily become the body politic." 55

\section{Divertissement Diversification}

The 1980s and 1990s proved to be a period of diversification within the Montreal dance world with artistic leaders and their companies striking off in multiple directions. Often, these efforts led to a global stage. As a result, one speaks of a Montreal dance scene as being among the most noteworthy in the North America.

In 1980, the already successful Édouard Lock, a member of Le Groupe Nouvelle Aire, formed a new company Lock Danseurs to perform his choreography with his collaborator dancer Louise Lecavalier as lead performer. ${ }^{56}$ The company's production Lily Marlène dans la jungle opened to rave reviews in Montreal's Théâtre l'Eskabel before moving to The Kitchen in New York. The group evolved into La La La Human Steps, which remained one of Montreal's most successful contemporary dance companies until it closed in September 2015 due to financial difficulties. ${ }^{57}$

Lock and La La La Human Steps were products of a Montreal scene, deeply rooted in the evolution of the city's performance dance community while simultaneously enjoying noteworthy success on the world stage. The company formed just as the city's cultural community was reaching out, partially in response to Quebec's new search for identity following the political failure of the sovereignty movement. This was a moment of prodigious creative energy ${ }^{58}$ It also was a moment that demanded more talent - especially more dancers - to keep pace with the imagination of its leaders - especially choreographers.

This insatiable demand prompted dance-teacherchoreographer Linda Rabin and dance-teacher Candace Loubert to found l'École Linda Rabin Danse Moderne in downtown Montreal in $1981 .^{59}$ Montreal native Rabin was returning home after studying with José Limón, Betty Jones and Anna Sokolow at Julliard in New York. She had worked in Israel as well as choreographed works for Les Grands Ballets Canadiens and other companies around the world. ${ }^{60}$ Loubert often drew on ritualistic dance traditions in India, Nepal, Japan, and Bali as she performed in Europe as well as with Les Grands Ballets Canadiens at home. ${ }^{61}$
Other companies followed, including Danse-Cité. Danse-Cité was the inspiration of Daniel Soulières, who founded the company in 1983 to promote contemporary dance before turning it over to choreographer JeanPierre Perreault. Soulières embraced dance after having completed his degree in psychology at l'Université de Montréal. Initially studying classical ballet, he turned to contemporary dance working with such leading teachers such as Peggy Baker, Peter Boneham, Linda Rabin, and Tassy Teekman. Soulières quickly became one of the most popular dancers in Montreal, performing an average of thirty-seven shows each year between 1977 and 1996. These productions included roles created for him by choreographers James Kudelka, Françoise Sullivan, Jeanne Renaud, and Paul-André Fortier among many. He himself choreographed and co-choreographed dozens of works. ${ }^{62}$

Around the same time, in 1986, Le Groupe Nouvelle Aire's Paul-André Fortier joined with Daniel Jackson to establish Montréal Danse to facilitate pioneering dance that challenges audiences and dancers together in an interactive relationship. Fortier choreographed works for Montréal Danse even as he continued to work with larger companies including Les Grands Ballets Canadiens. He taught dance at l'UQÀM following his retirement from performance in $1989 .{ }^{63}$

Fortier and Jackson were innovative organizationally as well. Seeking to promote the company as a collective enterprise, they named no permanent choreographer. ${ }^{64}$ Instead, the company deepened its commitment to partnerships with multiple cutting-edge artists. This perishability has lasted permanently for more than thirty years with Montréal Danse retaining pride of place on the Montreal dance scene.

\section{From Le Refus Global to La Danse Globale}

The twenty-first century began with Montreal well established as a significant international center for performance dance, and a global leader in the two dancerelated genres of physical theater and circus arts. One might have thought this always was so. However, just a half-century before, Quebec's clerical arbiters of public taste had frowned on physical artistic expression in almost any form. 
The emergence of first classical, then modern and contemporary dance in Montreal is inexorably linked to broader changes in society that drove political conflict and deep cultural wars. The Quebec transformation to modernity is no less dramatic for being swift and largely peaceful. Accompanying dislocations drove the preeminence of the arts - including literature, theatre, cinema, television, circus, music or dance - as a form of bringing together high culture with street performance. ${ }^{65}$

Dance became embedded in Montreal life - a space in which it had largely been absent - because the dance community constructed a broad range of supporting institutions ranging from studios and schools. Les Grand Ballets Canadiens, Le Ballet Jazz de Montréal, the dance programs at l'UQÀM and Concordia, provincial and federal arts programs, and arts spaces such as l'Agora de la danse combined to produce a solid foundation on which artistic talent could take flight. Dance thrived in Montreal because it became rooted in local society by interacting with it.

Each of these components allowed a once disparaged art form to attain pride of place in a single lifetime. They produced precisely the resplendent anarchy Françoise Sullivan and the other petitioners signers of Le Refus Global extolled as a primal source of cre- ativity. Or, as Sullivan herself would note four decades later in a 1988 address at Toronto's York University published in Odom and Warner's Canadian Dance, "art can only flourish if it grows from problems which concern the age, and is always pushed in the direction of the unknown. Hence, the marvelous in it." 66

These essentials - and the visionaries that created them - similarly prepared Montreal dance for the trials of the century to follow. With dozens of dance schools and hundreds of dancers, the world of twenty-first century dance in Montreal is highly organized, complex, and dynamic. Opportunities exist from studios for children just discovering dance to internationally recognized and celebrated companies, choreographers, and dancers. From classical, to modern, to avant-garde and experimental, audiences and professionals move back and forth among genres, often interacting with varied subcommunities as they do.

Following World War II, pioneers such as the Morenoffs, Gérard Crevier, Françoise Sullivan, and Ludmilla Chiriaeff were viewed as exotics performing in school basements, library halls, gymnasiums and televisions studios. Now everyone can find his or her place on increasingly specialized stages secured by deep connections with the world at large.

\section{ENDNOTES}

${ }^{1}$ Pénélope Clermont, "La danse célébrée par 10,000 personnes," Journal La Revue de Terrebonne (April 26, 2016).

${ }^{2}$ Micheline Milot, "The Priest-Ridden Province? Politics and Religion in Quebec," in Stéphan Gervais, Christopher Kirkey and Jarret Rudy, editors, Quebec Questions. Quebec Studies for the Twenty-First Century (Toronto: Oxford University Press Canada, 2011), pp. 123-136.

${ }^{3}$ Iro Valaskakis Tembeck, "Dancing in Montreal. Seeds of a Choreographic History," Studies in Dance History, Vol. V, No. 2 (1994), pp. 1-146: 1-10; and, Andrew Oxenham with Michael Crabb, Dance Today in Canada (Toronto: Simon \& Pierre Publishing Co, Ltd., 1977), pp. 7-14.

${ }^{4}$ Iro Tembeck, "Dancing in Montreal. Seeds of a Choreographic History," pp. 22-23; Karen Stanworth, "Re-Placing Performance: The Inter-Media Practice of François Sullivan," in Selma Landen Odom and Mary Jane Warner, editors, Canadian Dance: Visions and Stories (Toronto: Dance Collection Danse Press, 2004), pp. 329-338; Robert Enright, "A Woman for All Seasons: An Interview with Françoise Sullivan," BorderCrossings (Issue 106) (May 2008); and, Dan Taylor, "Refus Global by Paul-Émile Borduas," (http://www.dantaylor.com/pages/frenchrefusglobal.html [accessed May 5, 2016]).

${ }^{5}$ Iro Valaskakis Tembeck, "Françoise Sullivan," in Susan Macpherson, editor, Encyclopedia of Theatre Dance in Canada / Encyclopédie de la Danse Théâtrale au Canada (Toronto: Dance Collection Danse Press, 2000), pp. 563-565.

6 Allana Lindgren, "François Sullivan: An introduction," in Selma Landen Odom and Mary Jane Warner, editors, Canadian Dance: Visions and Stories, pp. 10-19. 
7 Linde Howe-Beck, “Jeanne Renaud," in Susan Macpherson, editor, Encyclopedia of Theatre Dance in Canada / Encyclopédie de la Danse Théâtrale au Canada, pp. 482-487.

${ }^{8}$ Geraldine Anthony, Stage Voices: Twelve Canadian Playwrights Talk about Their Lives and Work (Toronto: Doubleday Canada, LTD., 1978), pp. xix-xxi.

9 Nick Mont, Arrival. The Story of CanLit (Toronto: Anasi, 2017), pp. 123-127; 181-194; and, Cheryl Smith, "Stepping Out: A New Look at Canada's Early Ballet Companies, 1939 to 1960," in Selma Landen Odom and Mary Jane Warner, editors, Canadian Dance: Visions and Stories, pp. 197-223: 216-220.

${ }_{10}$ Roger Lemelin," Canadian Writers Website (http://www.collectionscamada/gc.ca/writers/027005-2000-e.html [accessed May 5, 2016]).

11 Geraldine Anthony, Stage Voices: Twelve Canadian Playwrights Talk about Their Lives and Work (Toronto: Doubleday Canada, LTD., 1978), pp. xxi-xxiii.

12 Iro Valaskakis Tembeck, "Maurice Lacasse Morenoff, Carmen Sierra Morenoff," and Linde Howe-Beck, "Jeanne Renaud," in Susan Macpherson, editor, Encyclopedia of Theatre Dance in Canada / Encyclopédie de la Danse Théâtrale au Canada, pp. 394-395 and 482-484.

13 Iro Tembeck, "Dancing in Montreal. Seeds of a Choreographic History," pp. 11-17.

${ }^{14}$ Iro Valaskakis Tembeck, “Maurice Lacasse Morenoff, Carmen Sierra Morenoff," p. 395; and Pierre Lapointe, Three Intrepid Montreal Dancers of the 1940s and 1950s," in Selma Landen Odom and Mary Jane Warner, editors, Canadian Dance: Visions and Stories, pp. 287-295.

15 Iro Tembeck, "Dancing in Montreal. Seeds of a Choreographic History," pp. 17-19.

16 Grant Strate, "Canadian Dance in Progress: A Personal View," in Selma Landen Odom and Mary Jane Warner, editors, Canadian Dance: Visions and Stories, pp. 21-32.

17 Iro Valaskakis Tembeck, "Gérald Crevier," in Susan Macpherson, editor, Encyclopedia of Theatre Dance in Canada / Encyclopédie de la Danse Théâtrale au Canada, pp. 394-395.

18 Linde Howe-Beck, "Ludmilla Chiriaeff," in Susan Macpherson, editor, Encyclopedia of Theatre Dance in Canada / Encyclopédie de la Danse Théâtrale au Canada, pp. 118-121.

19 Cheryl Smith, “Stepping Out: A New Look at Canada's Early Ballet Companies, 1939 to 1960," pp. $214-219$.

${ }^{20}$ Iro Valaskakis Tembeck, "Politics and Dance in Montreal, 1940s to 1980s: The Imaginary Maginot Line between Anglophone and Francophone Dancers," in Selma Landen Odom and Mary Jane Warner, editors, Canadian Dance: Visions and Stories, pp. 278-280.

${ }^{21}$ Cheryl Smith, “Stepping Out: A New Look at Canada's Early Ballet Companies, 1939 to 1960," pp. 197-223; and Katherine Cornell, "The Ballet Problem: The Kirstein-Buckle Ballet Survey for the Canada Council," in Selma Landen Odom and Mary Jane Warner, editors, Canadian Dance: Visions and Stories, pp. 225-238.

22 Iro Tembeck, "Dancing in Montreal. Seeds of a Choreographic History," pp. 23-25.

${ }^{23}$ Ibid, pp. 25-28.

${ }^{24}$ Ibid, pp. 28-32.

${ }^{25}$ Cheryl Smith, "Stepping Out: A New Look at Canada's Early Ballet Companies, 1939 to 1960."

${ }^{26}$ Katherine Cornell, "The Ballet Problem: The Kirstein-Buckle Ballet Survey for the Canada Council."

27 Cheryl Smith, “Stepping Out: A New Look at Canada’s Early Ballet Companies, 1939 to 1960," p. 221.

${ }^{28}$ Les Grands Ballets Canadiens de Montréal," The Canadian Encyclopedia [www. thecanadianencyclopedia.ca/ [May 20, 2016]).

${ }^{29}$ Les Grands Ballets Canadiens de Montréal," The Canadian Encyclopedia [www. thecanadianencyclopedia.ca/ [May 20, 2016]).

${ }^{30}$ Michael Gauvreau, Catholic Origins of Quebec's Quiet Revolution, 1931-1970 (Montreal: McGill-Queen's Press, 2005); and, Michael D. Behiels, Prelude to Quebec's Quiet Revolution: Liberalism vs Neo-Nationalism, $1945-60$ (Montreal: McGillQueen's Press, 1985).

${ }^{31}$ Sylvain Schryburt, "Quebec Theatre: New Dynamics between the Local and International," in Stéphan Gervais, Christopher Kirkey and Jarret Rudy, editors, Quebec Questions. Quebec Studies for the Twenty-First Century, pp. 443-455; and, Gregory J. Reid, "Performing Anglo Quebec: The Myth of Solitudes and Merging Anglo-Québécois Subject," Journal of Canadian Studies, vol. 46, no. 3 (2012), pp. 105-127.

32 Paul-Andre Linteau, The History of Montreal: The Story of a Great North American City [trans. By Peter MacCambridge] (Montreal: Baraka Books, 2013), p. 166.

33 Andrew Oxenham with Michael Crabb, Dance Today in Canada, p. 27-28.

34 Linde Howe-Beck, "Ludmilla Chiriaeff." 
${ }^{35}$ Linde Howe-Beck, "Les Grands Ballets Canadiens," in Susan Macpherson, editor, Encyclopedia of Theatre Dance in Canada / Encyclopédie de la Danse Théâtrale au Canada, pp. 241-245.

${ }^{36}$ Iro Tembeck, "Dancing in Montreal. Seeds of a Choreographic History," pp. 38-39.

37 Iro Valaskakis Tembeck, "Politics and Dance in Montreal, 1940s to 1980s: The Imaginary Maginot Line between Anglophone and Francophone Dancers," p. 279.

${ }^{38}$ Jo Leslie, "Le Groupe de la Place Royale," in Susan Macpherson, editor, Encyclopedia of Theatre Dance in Canada / Encyclopédie de la Danse Théâtrale au Canada, pp. 250-253.

${ }^{39}$ Iro Tembeck, "Dancing in Montreal. Seeds of a Choreographic History," pp. 47-48.

${ }^{40}$ Lai-Ling Lee, "Peter Boneham," in Susan Macpherson, editor, Encyclopedia of Theatre Dance in Canada / Encyclopédie de la Danse Théâtrale au Canada, pp. 89-91.

${ }^{41}$ Jo Leslie "Le Groupe de la Place Royale."

${ }_{42}$ "Le Groupe de la Place Royale," The Canadian Encyclopedia [www.thecanadianencyclopedia.ca/ [May 20, 2016]).

43 “Le Groupe Dance Lab," The Canadian Encyclopedia [www.thecanadianencyclopedia.ca/ [June 11, 2016]).

${ }^{44}$ Ibid.

45 Iro Tembeck, "Dancing in Montreal. Seeds of a Choreographic History," pp. 58-61.

${ }^{46}$ Iro Valaskakis Tembeck, "Politics and Dance in Montreal, 1940s to 1980s: The Imaginary Maginot Line between Anglophone and Francophone Dancers," pp. 280-282.

47 "Le Groupe Nouvelle Aire," The Canadian Encyclopedia [www.thecanadianencyclopedia.ca/ [June 14, 2016]); and Martine Époque, Les coulisses de la nouvelle danse au Québec, Le Groupe Nouvelle Aire en mémoires, 1968-1982 (Sanite-Foy: Presses de l'Université du Québec, 1999); and Andrew Oxenham with Michael Crabb, Dance Today in Canada, pp. 30-35. ${ }^{48}$ Iro Valaskakis Tembeck, "Martine Époque," in Susan Macpherson, editor, Encyclopedia of Theatre Dance in Canada / Encyclopédie de la Danse Théâtrale au Canada, pp. 178-180.

49 Aline Gélinas, "Paul-André Fortier, in Ibid, pp. 198-200.

${ }^{50}$ Kathryn Greenaway, "Ginette Laurin," in Ibid, pp. 330-332.

${ }^{51}$ Linde Howe-Beck, "Eva von Gencsy," in Ibid, pp. 611-613.

52 Ibid.

53 Ibid.

${ }^{54}$ Lys Stevens, "Eva von Gencsy (1924-2013)," The Dance Current (December 4, 2013).

55 Iro Valaskakis Tembeck, "Politics and Dance in Montreal, 1940s to 1980s: The Imaginary Maginot Line between Anglophone and Francophone Dancers," p. 284.

${ }^{56}$ Kathryn Greenaway, "Éduard Lock" in Susan Macpherson, editor, Encyclopedia of Theatre Dance in Canada / Encyclopédie de la Danse Théâtrale au Canada, pp. 357-359.

57 Victor Swoboda, "La La La Human Steps is no more, Édouard Lock announces," Montreal Gazette (September 2, 2015).

${ }^{58}$ Iro Tembeck, "Dancing in Montreal. Seeds of a Choreographic History," pp. 86-92.

${ }^{59}$ Linde Howe-Beck, "École de danse contemporaine de Montréal, The Canadian Encyclopedia [www.thecanadianencyclopedia.ca/ [June 27, 2016]).

${ }^{60}$ Kathryn Greenaway, "Linda Rabin," in Susan Macpherson, editor, Encyclopedia of Theatre Dance in Canada / Encyclopédie de la Danse Théâtrale au Canada, pp. 469-471.

${ }^{61}$ Samantha Mehra, "Candace Loubert (1947-2011)," The Dance Current. Canada's Dance Magazine (November 23, 2011).

${ }^{62}$ Linde Howe-Beck, "Daniel Soulièrs," in Susan Macpherson, editor, Encyclopedia of Theatre Dance in Canada / Encyclopédie de la Danse Théâtrale au Canada, pp. 543-545.

${ }_{63}$ Aline Gélinas, "Paul-André Fortier," in Ibid, pp. 198-200.

${ }^{64}$ Iro Tembeck, "Dancing in Montreal. Seeds of a Choreographic History," p. 86.

${ }^{65}$ Christopher Jones, "Popular Music in Quebec," in Stéphan Gervais, Christopher Kirkey and Jarret Rudy, editors, Quebec Questions. Quebec Studies for the Twenty-First Century, pp. 212-226; Sylvain Schryburt, "Quebec Theatre: New Dynamics between the Local and the International," in Ibid, pp. 443-454; and, Thomas A. Cummins-Russell and Norma M. Rantisi, "Networks and Place in Montreal's Independent Music Industry," The Canadian Geographer, vol. 56, no. 1 (2012), pp. 80-97.

${ }^{66}$ François Sullivan, "Dance and Hope," in Selma Landen Odom and Mary Jane Warner, editors, Canadian Dance: Visions and Stories, n pp. 11-18: 16. 